\title{
Heavy Metal Ions Removal from Aqueous Solutions by Treated Ajwa Date Pits: Kinetic, Isotherm, and Thermodynamic Approach
}

\author{
Mohammad Azam *, Saikh Mohammad Wabaidur (D), Mohammad Rizwan Khan (D), Saud I. Al-Resayes \\ and Mohammad Shahidul Islam (D)
}

check for

updates

Citation: Azam, M.; Wabaidur, S.M.; Khan, M.R.; Al-Resayes, S.I.; Islam, M.S. Heavy Metal Ions Removal from Aqueous Solutions by Treated Ajwa Date Pits: Kinetic, Isotherm, and Thermodynamic Approach. Polymers 2022, 14, 914. https://doi.org/ $10.3390 /$ polym 14050914

Academic Editors: Stefano Vecchio Ciprioti and Arn Mignon

Received: 21 November 2021

Accepted: 9 February 2022

Published: 25 February 2022

Publisher's Note: MDPI stays neutral with regard to jurisdictional claims in published maps and institutional affiliations.

Copyright: (C) 2022 by the authors. Licensee MDPI, Basel, Switzerland. This article is an open access article distributed under the terms and conditions of the Creative Commons Attribution (CC BY) license (https:// creativecommons.org/licenses/by/ $4.0 /)$.
Department of Chemistry, College of Science, King Saud University, P.O. Box 2455, Riyadh 11451, Saudi Arabia; swabaidur@KSU.EDU.SA (S.M.W.); mrkhan@ksu.edu.sa (M.R.K.); sresayes@ksu.edu.sa (S.I.A.-R.); mislam@KSU.EDU.SA (M.S.I.)

* Correspondence: mhashim@ksu.edu.sa

\begin{abstract}
In the current study we prepared cost-effective adsorbents based on ajwa date pits to remove $\mathrm{Cu}(\mathrm{II})$ ions from aqueous medium. Adsorbents were studied using scanning electron microscopy (SEM), FT-IR, and Brunauer-Emmett-Teller (BET) methods to characterize the surface functionalities, morphology, pore size, and particle size. The concentration of $\mathrm{Cu}(\mathrm{II})$ ions in the studied samples was determined by atomic adsorption spectrometry technique (AAS). Adsorption method was performed sequentially in a batch system followed by optimization by studying the numerous conditions, for instance the initial amounts of $\mathrm{Cu}(\mathrm{II})$ ions, dosages of the adsorbent, contact time, and $\mathrm{pH}$ of the solution. The ideal $\mathrm{pH}$ observed for maximum adsorption capacity was $~ 6.5$. Langmuir and Freundlich isotherm models correctly predicted the investigation results, with the maximum monolayer adsorption capacities for $\mathrm{Cu}$ (II) ions at $328 \mathrm{~K}$ being $1428.57 \mathrm{mg} / \mathrm{g}$ (treated ajwa date pits, TADP) and $1111.1 \mathrm{mg} / \mathrm{g}$ for as produced ajwa date pits (ADP). It was revealed that TADP possess greater adsorption capability than ADP. Recovery investigations revealed that the saturated adsorbents eluted the maximum metal with $0.1 \mathrm{M} \mathrm{HCl}$. $\mathrm{Cu}(\mathrm{II})$ ions adsorption was observed to be reduced by $80-89 \%$ after the second regeneration cycle. For the raw and chemically processed ajwa date pits adsorbent, the Langmuir model performed significantly better than the Freundlich model. The results demonstrated that the adsorbent made from ajwa date pits could be an economical and environmentally friendly alternative for removing $\mathrm{Cu}$ (II) ion pollutant from aqueous media.
\end{abstract}

Keywords: biosorbent; copper; adsorption; model studies; aqueous medium

\section{Introduction}

Heavy metals hazardous waste has currently become one of the most serious environmental issues [1,2]. Heavy metal contamination accumulates in the environment and is not naturally decomposable, posing a concern to human health [3,4]. Cu(II) ion is a heavy metal ion that is widely used in a variety of manufacturing industries, including fertilizer, paints, plating baths, and paper goods [5-8]. The discharges from these sources contain a significant amount of $\mathrm{Cu}$ (II) ions, which are discharged into the environment via watercourses and earth [7,8]. It eventually combines with the food chain to cause a variety of severe human ailments [9]. Long-term copper exposure is harmful to health and can cause several diseases such as diarrhoea, vomiting, central nervous system and, mucosal irritation, hepatic, gastrointestinal distress and, kidney and liver damage [10-14]. In addition, if a high quantity of copper salts is consumed, it forms severe copper toxicity in individuals, most likely because of redox cycling and the production of reactive oxygen species that harm deoxyribonucleic acid [15,16]. Regarding its exposure to human, the US Occupational Safety and Health Administration has labelled an allowable exposure limit for copper fumes and dusts in the workplace as a time-weighted average of $1 \mathrm{mg} / \mathrm{m}^{3}$ [17]. The 
National Institute for Occupational Safety and Health has fixed a suggested exposure limit of $1 \mathrm{mg} / \mathrm{m}^{3}$ as the time-weighted average. The immediate risk to life and health concentration is $100 \mathrm{mg} / \mathrm{m}^{3}$ [17]. Recently, the National Primary Drinking Water Regulations of the USEPA has also regulated the levels of $\mathrm{Cu}(\mathrm{II})$ in drinking water with MCL of $1.3 \mathrm{mg} / \mathrm{L}$ [14]. The $\mathrm{Cu}(\mathrm{II})$ ion has also been regulated by the National Primary Drinking Water Regulations of the United States Environmental Protection Agency (USEPA) in drinking water with a Maximum Contaminant Level (MCL) of $1.3 \mathrm{mg} / \mathrm{L}$.

Several traditional techniques such as ion-exchange [18], oxidation [19], electrocoagulation [20], solvent extraction [21], chemical precipitation [22], ultrafiltration [23], adsorption [24], activated carbon [25], membrane separation [26], and evaporation [27] have been applied to eliminate heavy metal ions. Nonetheless, most of these techniques have some drawbacks such as high production cost, consumption of high energy, high volumes of waste, and challenging treatment systems. Although, the adsorbent based on activated carbon has great microporous features, including high adsorption capacity and high surface area, it has demonstrated its capability as an adsorbent for the heavy metals removal from wastewater [28]. However, the application of activated carbon is very costly, with moderately high operational overheads. In addition, there is a requirement of regeneration prior to each adsorption phase [25]. Among these procedures, adsorption has been the most extensively accepted process because of its simplicity, versatility, ecofriendly, and being highly cost effective [24]. However, for the present, there is a rising demand to discover effortlessly obtainable, highly efficient, and very cost effective adsorbents for the adsorption of $\mathrm{Cu}$ (II) ions from different matrices. Cashew nut shell [5], saw dust [29], spent grain [30], wheat straw [31], pine cone powder [32], sawdust [33], herbaceous peat [34], peanut hull [6] sugar beet pulp [35], and others [36-39] are examples of effective adsorbents to remove copper ions. Due to the great obtainability and low-price of these adsorbents a complex regeneration method is not needed, and this cheaper adsorption system has involved numerous researchers. Thus, in order to substitute the current marketable materials, we have chosen ajwa date pits as the adsorbent, because Saudi Arabia is the world's third main producer of dates, and date pits are easily available and free of cost. In addition, the occurrence of numerous functional groups, for instance amino acid, carboxylic acid, phenols, ester, hydroxyl, and carboxylate can assist them as possible adsorbents for heavy metals removal from aqueous medium [40]. Therefore, we have developed adsorbents to remove $\mathrm{Cu}$ (II) ions from aqueous medium that are both cost effective and high-yielding, and are derived from a common waste product-ajwa date pits. Hydrogen peroxide $\left(\mathrm{H}_{2} \mathrm{O}_{2}\right)$ treatment enhanced the surface functionalities $(-\mathrm{OH})$ of the synthesized ADP powder. The raw and treated materials were characterized by different methods, for instance SEM, FT-IR and BET, certifying the excellent particle size, surface morphology, and adsorption capabilities. Several investigational parameters, including solution contact time, $\mathrm{pH}$, starting concentration, and $\mathrm{Cu}(\mathrm{II})$ ion temperature, were also studied. Langmuir and Freundlich adsorption isotherms were applied to study the equilibrium modelling [36]. Thermodynamic and kinetic characteristics have been applied to assess the nature of the sorption method. In this study, we are using ajwa date pits as adsorbents for the first time to remove $\mathrm{Cu}(\mathrm{II})$ heavy metal ion from an aqueous solution.

\section{Materials and Methods}

\subsection{Chemicals and Reagents}

All the chemicals and reagents namely, copper(II) chloride $\left(\mathrm{CuCl}_{2}\right)$, sodium hydroxide $(\mathrm{NaOH})$, hydrochloric acid $(\mathrm{HCl})$, sodium hydroxide $(\mathrm{NaOH})$, and $\mathrm{H}_{2} \mathrm{O}_{2}, 30 \% v / v$ were of analytical grade, and were obtained from Sigma-Aldrich (Steinheim, Germany). A stock solution of $\mathrm{Cu}$ (II) ion $(1000 \mu \mathrm{g} / \mathrm{mL})$ prepared in ultrapure water was purified using Milli$\mathrm{Q}$ water purification system (Millipore Corporation, Bedford, NH, USA). For complete mixing, the solution was agitated for $5 \mathrm{~min}$. The required $\mathrm{Cu}$ (II) ion test solutions were prepared by suitable successive dilutions of the stock solution. For calibration purposes 
the, concentration range of the $\mathrm{Cu}(\mathrm{II})$ ion ranged from 1 to $10 \mu \mathrm{g} / \mathrm{mL}$. The $\mathrm{pH}$ of solutions was adjusted to the optimum value by $\mathrm{NaOH} / \mathrm{HCl}$.

\subsection{Instrumentation}

The amount of $\mathrm{Cu}$ (II) ion was identified by high-throughput atomic absorption spectrometry (AAS) (Thermo Scientific, Waltham, MA, USA). The point of zero charge was measured by means of the salt addition process (pHPZC). The surface morphology of the synthesized and treated date pit materials was determined using SEM (Jeol JSM 5400 L $\mathrm{V}$, Tokyo, Japan). The surface functionalities present on the produced biosorbents were determined using FT-IR (Thermo Scientific Nicolet 6700, Waltham, MA, USA) with 1:100 wt ratio of $\mathrm{KBr}$ dilution equivalent to the $400 \mathrm{~cm}^{-1}$ and $4000 \mathrm{~cm}^{-1}$ wave numbers, obtained at 32 scans average value with a $\pm 4 \mathrm{~cm}^{-1}$ resolution applied. Multifunctional X-ray diffractometer (XRD, Ultima IV, Rigaku, Charlestown, MA, USA) was used to determine the surface crystallinity and average particle size of the samples. The surface area and pore size of the samples were measured by BET surface area analyzer (Micromeritics-Gemini VII 2390 V1.03, Norcross City, GA, USA).

\subsection{Biosorbent Preparation}

The ajwa dates $(5 \mathrm{~kg}$ ) were purchased from Kingdom Dates, Riyadh Saudi Arabia. The date pits were removed and thoroughly rinsed with MilliQ water to exclude any remnants of edible portion and dust materials, then sun dried for many days, and then dried in an oven for $2 \mathrm{~h}$ at $80^{\circ} \mathrm{C}$. The date pits were mechanically crushed and processed in a ball mill, homogenized, and sieved at $120 \mu \mathrm{m}$ (Figure 1) [39,41].
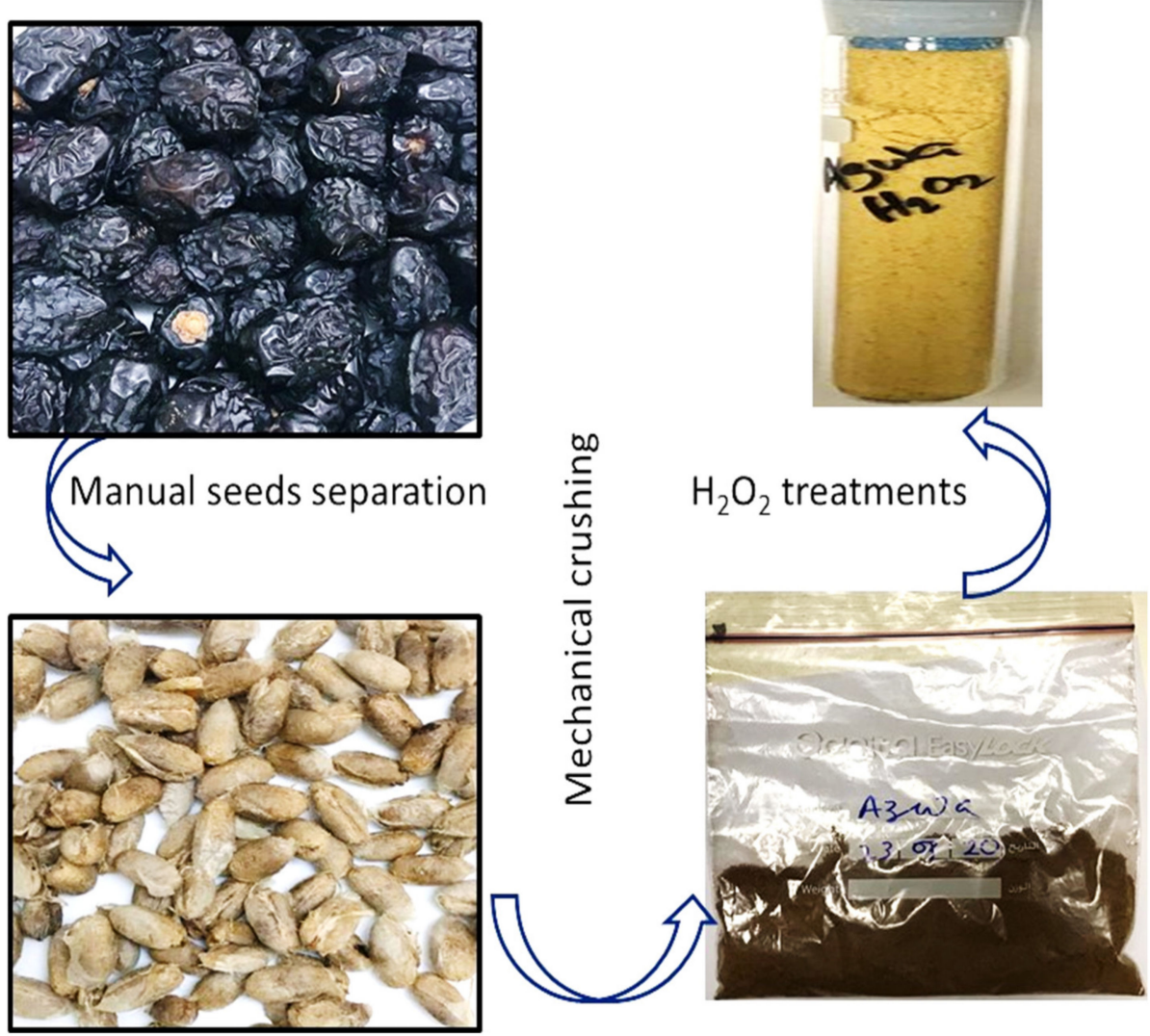

Figure 1. Ajwa dates, pits, and treated and untreated dates powders.

To establish the negative functionalities (-OH) onto the surface of the ADP adsorbent, the prepared ADP adsorbents were treated with $200 \mathrm{~mL}$ of $30 \% \mathrm{H}_{2} \mathrm{O}_{2}(v / v)$. Treatment with $\mathrm{H}_{2} \mathrm{O}_{2}$ also offers advantages to decompose organic parts, reduction of biomass resistance, 
and to avert the ADP cellulose degradation [41]. To perform the treatment procedure, ajwa date powder $(10 \mathrm{~g})$ was taken out in a beaker $(100 \mathrm{~mL})$ followed by the addition of the $\mathrm{H}_{2} \mathrm{O}_{2}$ solution $(100 \mathrm{~mL})$. The solution was then thoroughly mixed overnight using a magnetic stirrer. The Buckner funnel was used to filter the sample suspension with a vacuum pump, which was then washed with MilliQ water to eliminate any remaining content of hydrogen peroxide, and dried in an oven overnight. The samples were then allowed to cool to room temperature and bottled in transparent glass vials for further analysis.

\subsection{Adsorption and Desorption Studies}

Batch adsorption tests were carried out to eliminate $\mathrm{Cu}(\mathrm{II})$ ions from aqueous media. ADP powder $(0.05 \mathrm{~g})$ was weighed in a cleaned Erlenmeyer flask (100 mL) and $\mathrm{Cu}(\mathrm{II})$ $(100 \mathrm{mg} / \mathrm{L}, \mathrm{C} 0)$ solution was added to the flask, which was shaken overnight at $100 \mathrm{rpm}$ on a shaker. The solution mixture was separated and kept in a cold, dry environment. The AAS method was employed to quantify the amounts of $\mathrm{Cu}$ (II) ion, $\mathrm{C}_{e}$ after the solution reached equilibrium.

At the time of equilibration time $\left(q_{e}\right)$ and arbitrary time $t\left(q_{t}\right)$, the adsorption $(\%)$ and $\mathrm{Cu}(\mathrm{II})$ ion removing property of the adsorbents were measured, as described in a previous study [41]:

$$
q(\%)=\frac{\left(C_{o}-C_{e}\right)}{C_{o}} \times 100,
$$

where $q$ is the adsorption, $C_{o}$ is the initial concentration, and $C_{e}$ is the equilibrium concentration.

$$
q_{e}=\left(C_{o}-C_{e}\right) \times \frac{V}{m}
$$

where $q_{e}$ is the adsorption capacity at equilibrium, $C_{o}$ is the initial concentration, $C_{e}$ is the equilibrium concentration, $\mathrm{V}$ is the volume $(\mathrm{L})$, and $\mathrm{m}$ is the mass of adsorbent $(\mathrm{g})$.

$$
q_{t}=\left(C_{o}-C_{t}\right) \times \frac{V}{m}
$$

where $q_{t}$ is the adsorption capacity at time $t$ concentration $(\mu \mathrm{g} / \mathrm{mL})$ of $\mathrm{Cu}(\mathrm{II})$ solution, $\mathrm{C}_{o}$ is the initial concentration, $C_{t}$ is the concentration at time $t$, and $V$ is the volume (L), $m$ is the mass of adsorbent $(\mathrm{g})$. The adsorption capacities of $\left(q_{e}\right)$ and $\left(q_{t}\right)$ were measured in milligrams per gram.

For the $\mathrm{pH}$ investigations, at a concentration of $25 \mathrm{mg} / \mathrm{L}$, the initial $\mathrm{pH}$ (pHi) of $\mathrm{Cu}$ (II) ions was changed from 2 to 10. At concentration 20-100 mg/L and temperatures 293-323 K, the effects of $\mathrm{Cu}(\mathrm{II})$ ion initial concentration $\left(C_{0}\right)$ on adsorption were tested.

Contact time (t) of $\mathrm{Cu}(\mathrm{II})$ ion adsorption was studied at $\mathrm{C}_{0}: 25 \mathrm{mg} / \mathrm{L}$ for periods ranging from $2 \mathrm{~min}$ to $24 \mathrm{~h}$.

$\mathrm{Cu}$ (II) ion solutions (50 mL; $25 \mathrm{mg} / \mathrm{L}$ ) were saturated for $24 \mathrm{~h}$ with the adsorbents $(0.05 \mathrm{~g})$ for desorption studies. The saturated adsorbents were moderately washed with MilliQ water to eliminate the un-adsorbed remnants of treated $\mathrm{Cu}(\mathrm{II})$ ions. The $\mathrm{Cu}(\mathrm{II})$ ion was then eluted from the saturated adsorbent using a variety of eluents, including $\mathrm{CH}_{3} \mathrm{COOH}, \mathrm{H}_{2} \mathrm{SO}_{4}, \mathrm{HNO}_{3}, \mathrm{NaOH}$, and $\mathrm{HCl}$ solutions $(50 \mathrm{~mL}, 0.1 \mathrm{~mol} / \mathrm{L}$ ). The percentage of desorption was calculated using the following amount of $\mathrm{Cu}$ (II) ions in the eluent:

$\%$ Desorption $=($ Desorbed amount of $\mathrm{Cu}(\mathrm{II})$ ions $/$ adsorbed amount of $\mathrm{Cu}(\mathrm{II})$ ions on adsorbent) $\times 100$

\subsection{Thermodynamic Studies of Cu(II) Ions Adsorption}

The thermodynamic conditions, which define adsorption spontaneity, are extremely important in adsorption investigations. The spontaneity of the adsorption process is demonstrated by a negative Gibb's free energy change $\left(\Delta G^{\circ}\right)$ at a known temperature. Equation (4) was used to calculate $\Delta G^{\circ}$

$$
\Delta G^{\circ}=-\mathrm{RT} \ln \mathrm{Ka} .
$$


Equation (5) was used to calculate the values for enthalpy change $\left(\Delta H^{\circ}\right)$ and entropy change $\left(\Delta S^{\circ}\right)$.

$$
\Delta G^{\circ}=\Delta H^{\circ}-T \Delta S^{\circ},
$$

where $\mathrm{R}, T$, and Ka represent the gas constant $(8.314 \mathrm{~J} / \mathrm{mol} \mathrm{K})$, temperature $(\mathrm{K})$, and Langmuir constant [42], respectively.

\section{Results and Discussion}

\subsection{Characterization}

3.1.1. Surface and Pore Size Analysis of Adsorbents

The morphology and physical properties of the adsorbent surfaces of the prepared ADP and TADP adsorbents were evaluated using SEM. The SEM images of ADP and TADP are shown in Figure 2B,C. There are numerous fragmented particles that resemble spots, which can be seen in the SEM images of ADP (Figure 2A-C), showing the porous character of the adsorbents appropriate for target metal adsorption [39]. However, Scanning Electron Microscopic images of TADP discovered that the TADP causes the formation of a larger porosity surface, when compared to the raw material (Figure 2D-F).

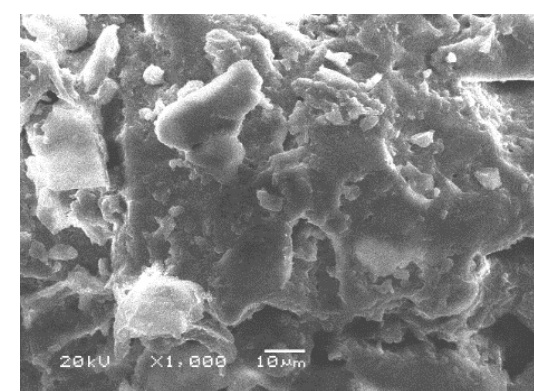

(A)

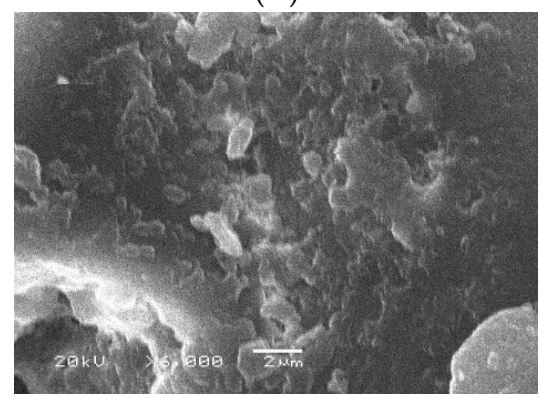

(C)

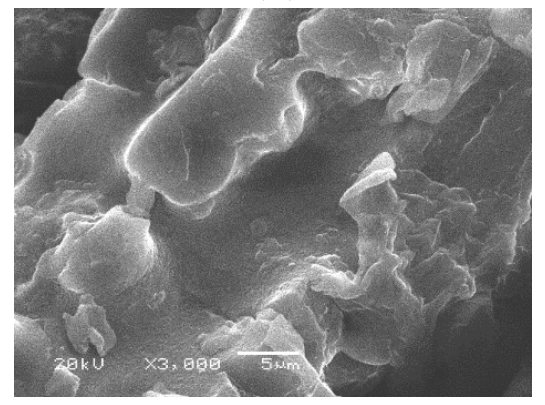

(E)

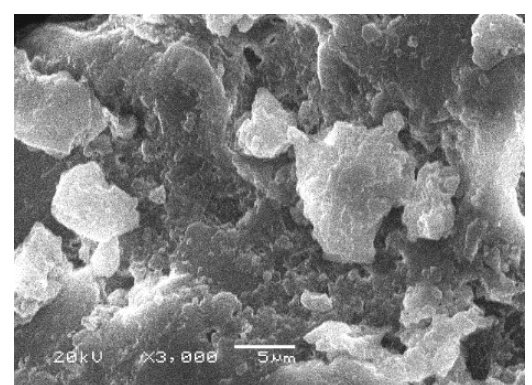

(B)

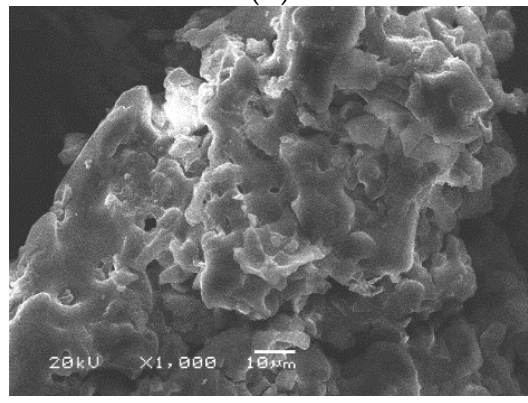

(D)

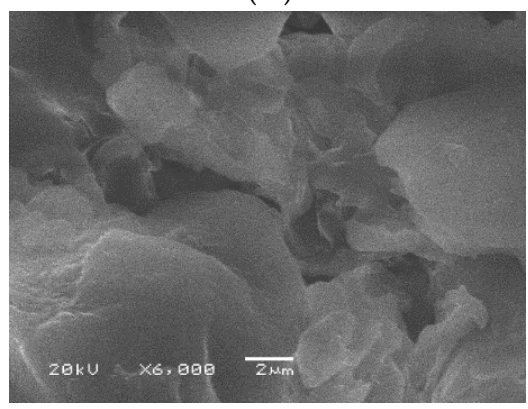

(F)

Figure 2. SEM images of ADP (A-C) and TADP (D-F) at various magnification: $1000 \times$ and $10 \mu \mathrm{m}$; $3000 \times$ and $5 \mu \mathrm{m}$ : and $6000 \times$ magnification with $2 \mu \mathrm{m}$ diameter.

The EDX analysis of the adsorbents was investigated to evaluate the composition of the active components presents in the adsorbents. The results indicate that the adsorbents are comprised of carbon as the major element ( 42 to $45 \%$ ) and other negative heteroatoms such as oxygen $\left(\mathrm{O}_{2}\right)$ and nitrogen $\left(\mathrm{N}_{2}\right)$ with a relatively lower percentage (21 to $\left.35 \%\right)$ 
compared to carbon (Table 1). It is obvious that the $\mathrm{H}_{2} \mathrm{O}_{2}$ treatment of ADP adsorbent shows higher contents of $\mathrm{O}_{2}$ as expected (35.8\%), which indicates successful modification of the ADP surface into negatively charged hydroxyl functionalities (Table 1).

Table 1. EDX analysis of the as-prepared ADP and TADP samples.

\begin{tabular}{|c|c|c|c|c|c|}
\hline \multirow{2}{*}{ Element } & \multirow{2}{*}{$(\mathrm{keV})$} & \multicolumn{4}{|c|}{ Mass $\%$} \\
\hline & & ADP & Error & TADP & Error \\
\hline C $\mathrm{K}$ & 0.277 & 45.37 & 0.15 & 42.96 & 0.21 \\
\hline $\mathrm{N} \quad \mathrm{K}$ & 0.392 & 25.60 & 0.68 & 21.18 & 0.45 \\
\hline $\mathrm{O} \mathrm{K}$ & 0.525 & 29.03 & 0.18 & 35.86 & 0.16 \\
\hline Total & & 100 & & 100 & \\
\hline
\end{tabular}

The powder X-ray diffraction analysis for the ADP and treated adsorbents (TADP) was carried out and displayed in Figure 3. The sharp peaks in the diffractograms indicates the crystalline nature of the prepared adsorbents, which were converted to wide peaks for $\mathrm{Cu}$ (II) ions saturated materials. This is likely due to the adsorption of metal ions on the surface of the materials, which caused the materials to change from crystalline to amorphous. The average crystallite size was also calculated by Scherrer's equation and was determined to be $27 \mathrm{~nm}$.

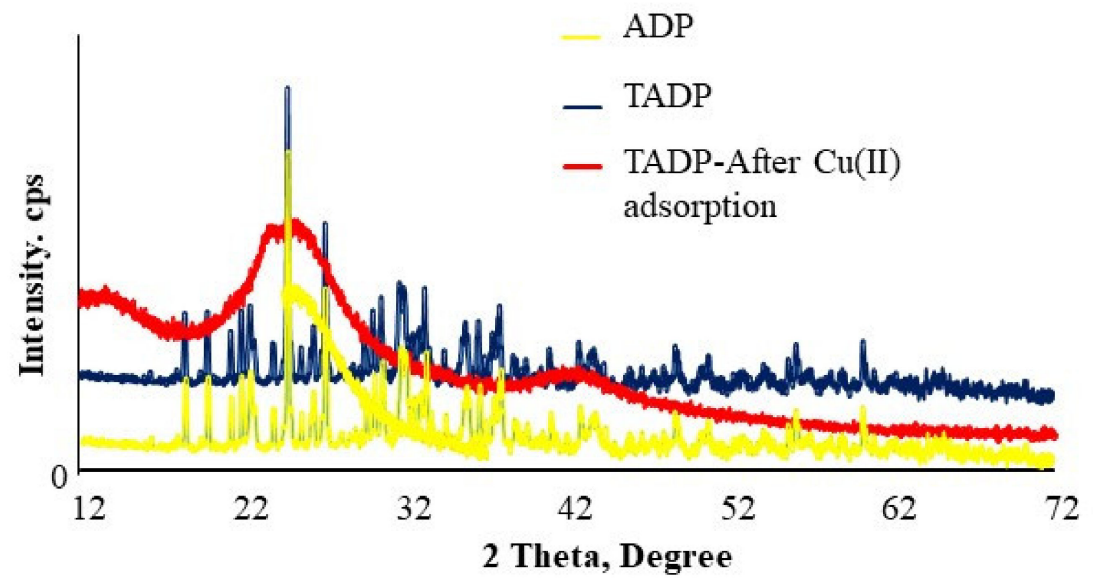

Figure 3. XRD analysis of ADP, TADP, and TADP after $\mathrm{Cu}(\mathrm{II})$ adsorption.

The BET surface areas for both ADP and TADP were determined to find the pore size of the materials (Figure 4). The surface area of TADP was found to be amplified from 2.47 to $8.48 \mathrm{~m}^{2} / \mathrm{g}$. The changes in pore areas show that during the $\mathrm{H}_{2} \mathrm{O}_{2}$ treatment of the ADP materials, increased porosity develops, resulting in higher adsorption efficiencies [41]. The adsorption average pore widths were also determined for ADP and TADP and were found to be in the range of $6-12 \mathrm{~nm}$.

\subsubsection{FTIR}

FTIR analysis was carried out to identify the surface functionalities and adsorption mechanism for ADP and TADP adsorbents before and after the adsorption $\mathrm{Cu}(\mathrm{II})$ ions (Figure 5). FTIR analysis helps to identify the functional groups as well as the bindings of the analyte with the adsorbents. The adsorbents materials are the lignocellulosic and are made up of lignin, cellulose, hemicellulose, and protein. Hydroxyl, ether, and carbonyl types oxygen-rich functionalities are abundant in both cellulosic and hemicellulose materials, which are mainly responsible for binding the metal ion with the adsorbent materials [41]. A broad peak in the FTIR spectra of both adsorbents at $3238-3570 \mathrm{~cm}^{-1}$ range, is attributed to the presence of the characteristic lignocellulosic peaks of $-\mathrm{OH},-\mathrm{NH}$, or both $-\mathrm{OH}$ and $\mathrm{NH}_{2}$ [35]. 


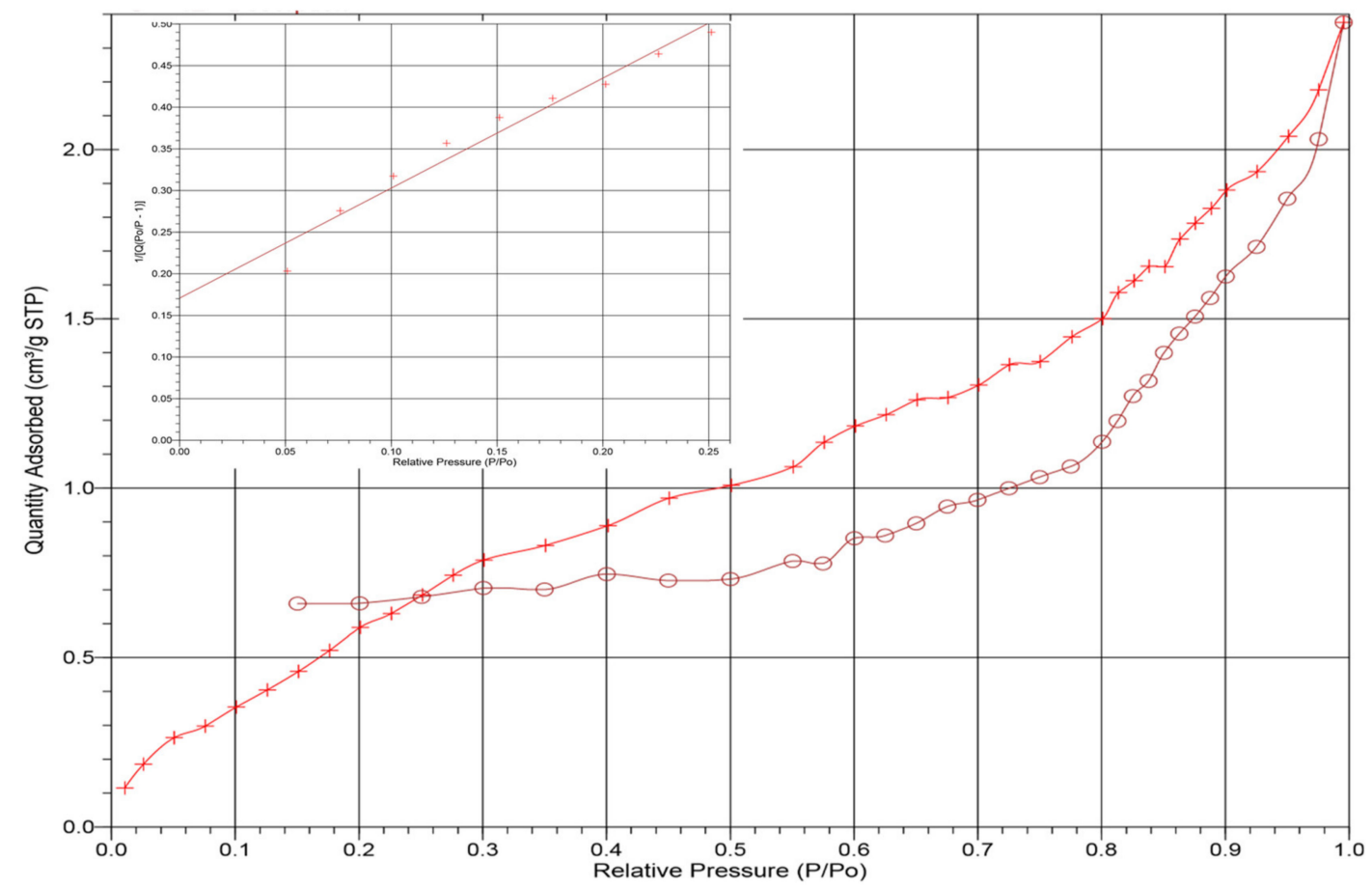

Figure 4. ADP linear isotherm plot with nitrogen adsorption plot (inset).

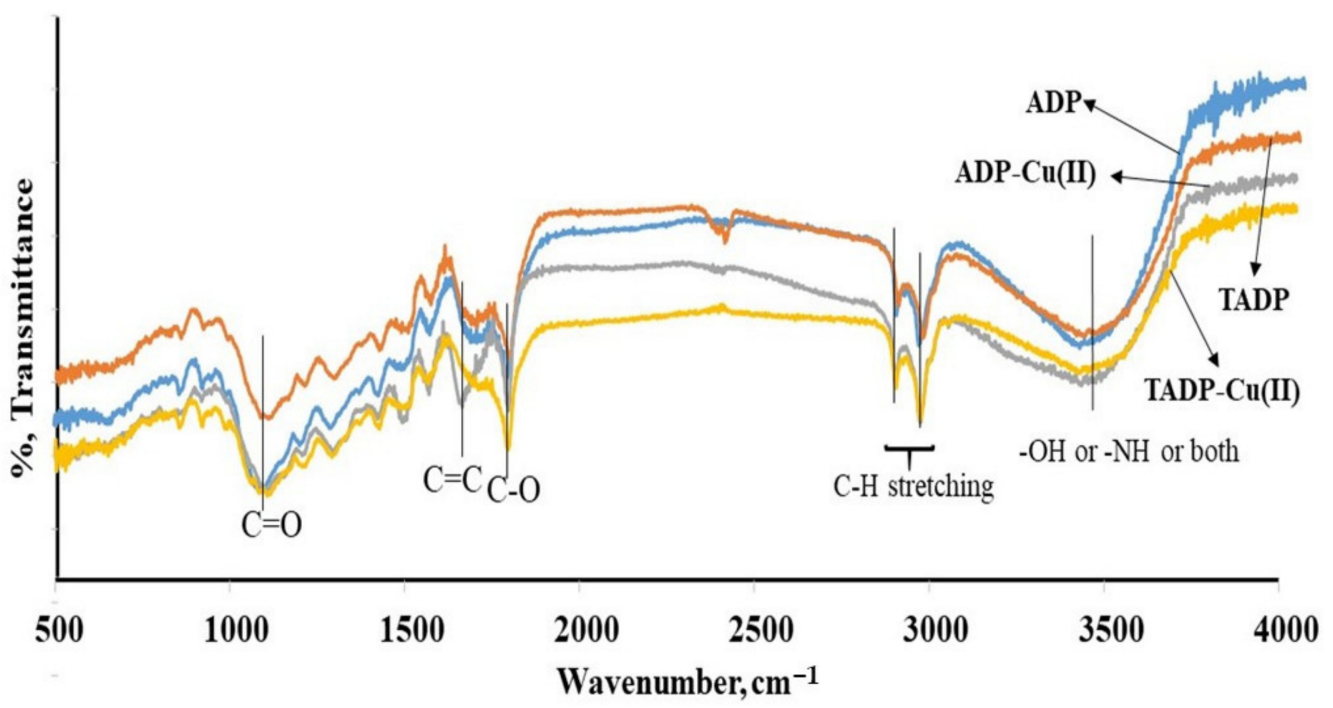

Figure 5. FT-IR analysis of ADP, ADP-Cu(II) ions, TADP, and TADP-Cu(II) ions (experimental conditions: initial conc. $25 \mathrm{mg} / \mathrm{L}$; adsorbent weight $0.005 \mathrm{~g}$; volume $0.05 \mathrm{~L}$; temperature $25{ }^{\circ} \mathrm{C}$; contact time $5 \mathrm{~h}$; shaker speed: $100 \mathrm{rpm}$ ).

The stretching vibrations of aliphatic $\mathrm{C}-\mathrm{H}$ functionalities are responsible for the absorbance peaks of 2927 and $2850 \mathrm{~cm}^{-1}$. The occurrence of unconjugated carbonyl $(\mathrm{C}=\mathrm{O})$, imine $(C=C)$ and $C-O$ functionalities is indicated by vibrations at 1745,1609 , and $1045 \mathrm{~cm}^{-1}$, respectively. The presence of small peaks in the spectral area between the $\mathrm{C}-\mathrm{O}$ and $\mathrm{C}=\mathrm{C}$, corresponds to bending peaks of $-\mathrm{CH}_{3}$ group $[34,36]$. The band at $514-708 \mathrm{~cm}^{-1}$ proved the existence of $-\mathrm{OH}$ polysaccharide groups. The number of small bands between the region 1410-1452 $\mathrm{cm}^{-1}$ appeared, owing to the presence of stretching vibrations of carboxylates (C-O and phenolic). Carboxylic acid and $\mathrm{C}-\mathrm{O}-\mathrm{C}$ vibrations were assigned to the bands appearing between 1210 and $1360 \mathrm{~cm}^{-1}$ and 1008 and $1159 \mathrm{~cm}^{-1}$, respectively.

The FTIR spectra of $\mathrm{Cu}(\mathrm{II})$ adsorbed ADP and TADP were also analyzed, and a minor shift in peaks (to higher wavenumbers) was observed at $3246-3580 \mathrm{~cm}^{-1}$ range, $1745 \mathrm{~cm}^{-1}$, 
and $1045 \mathrm{~cm}^{-1}$ as well as slight increases in those peak intensities, indicating the $\mathrm{Cu}$ (II) adsorption on adsorbents. The participation of the appropriate moieties $(-\mathrm{OH},-\mathrm{NH}, \mathrm{C}-\mathrm{O}$, and $\mathrm{C}=\mathrm{O}$ ) in the adsorption of target metal ions is confirmed by small shifts and increases in peak intensities of such peaks. Furthermore, these findings reveal that the increased electronegativity of heteroatoms and the lone pair of electrons of the $\mathrm{C}=\mathrm{O}, \mathrm{C}-\mathrm{O}$, and $-\mathrm{OH}$ or NH functional groups are mostly liable for the coordination binding and electrostatic interactions that bind $\mathrm{Cu}(\mathrm{II})$ ions to the adsorbent surface [43].

\subsection{Adsorption Properties}

\subsubsection{Effect of $\mathrm{pH}$ of the Solution}

$\mathrm{Cu}(\mathrm{II})$ adsorption on ADP and TADP was studied for initial $\mathrm{pH}\left(\mathrm{pH}_{\mathrm{i}}\right)$ values ranging from 2.7 to 10.5 . $\mathrm{pH}$ values higher than this range was omitted to avoid metal precipitation [41]. Because the $\mathrm{Cu}(\mathrm{II})$ metal ion was discovered to be cationic in the solutions phase, adsorption competition between the proton $(\mathrm{H}+)$ and metal ions is more likely at lower $\mathrm{pH}$. This may be responsible for lower adsorption of the metal at highly acidic environments (Figure 6). Cu(II) ion adsorption capabilities rapidly increased after initial slowing, with maximum adsorption capacities of $131 \mathrm{mg} / \mathrm{g}$ and $177 \mathrm{mg} / \mathrm{g}$ for ADP and TADP at pH 6.5, respectively. The adsorption capacities of both adsorbents steadily decreased upon increasing the $\mathrm{pH}$ of the adsorption media (Figure 6).
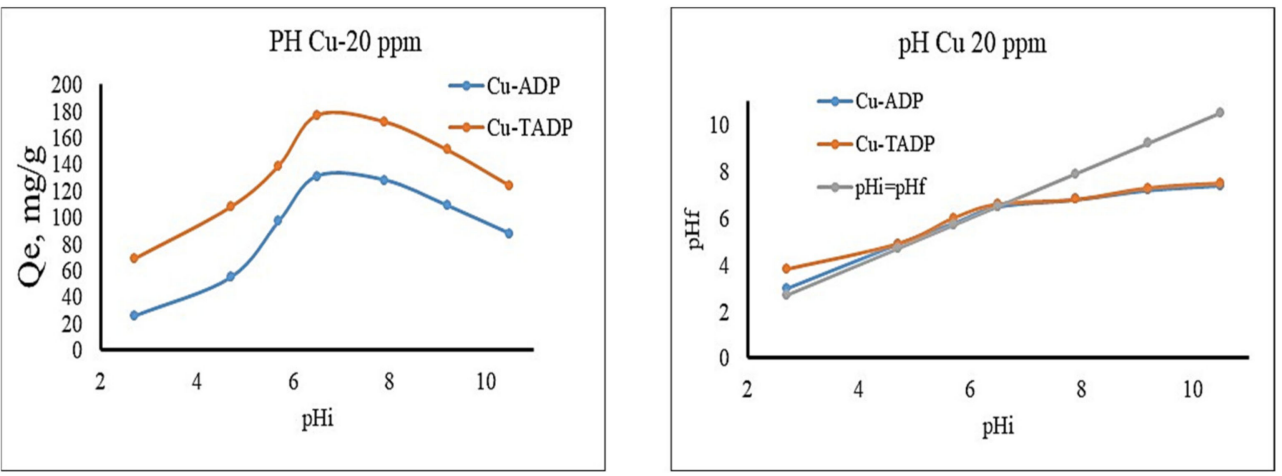

Figure 6. Adsorption capacity (qe) as a function of initial $\mathrm{pH}(\mathrm{pHi}$ ) and $\mathrm{pHi}$ versus $\mathrm{pHf}$ (final $\mathrm{pH}$ ) plot for $\mathrm{Cu}$ (II) adsorption onto ADP and TADP. (Optimal conditions: initial concentration $25 \mathrm{mg} / \mathrm{L}$; adsorbent weight $0.005 \mathrm{~g}$; volume $0.05 \mathrm{~L}$; temperature $25^{\circ} \mathrm{C}$; contact time $5 \mathrm{~h}$; shaker speed $100 \mathrm{rpm}$ ).

$\mathrm{Cu}$ (II) ion adsorption was highest at $\mathrm{pH}$ 6.5, which was higher than the point of zero charges $\left(\mathrm{pH}_{\mathrm{PZC}}\right)$, and $\mathrm{pH} 6.4$ for both ADP and TADP (Figure 6). The $\mathrm{pH}_{\mathrm{PZC}}$ value becomes zero at $\mathrm{pH}$ 6.4, confirming the neutral surface of the adsorbent materials. The surfaces of the adsorbents become positively and negatively charged, respectively, below and above this pHpzc, suggesting that the surfaces of TMDP and TSDP are more likely too protonated under acidic conditions to prevent metal ion adsorption.

Furthermore, as the $\mathrm{pH}$ increases, protonation decreases, resulting in a decrease in surface positivity and an enhancement in $\mathrm{Cu}$ (II) ion binding over the ADP and TADP surfaces. Above pH 6.5, a drop in the pH graph was observed (Figure 6), indicating that the adsorbents surface was neutralized in combination with the adsorption equilibrium.

\subsubsection{Effect of Initial Concentration and Temperature}

To determine the corresponding equilibrium isotherms, a different concentration of $\mathrm{Cu}$ (II) adsorption ranging from 10 to $50 \mathrm{mg} / \mathrm{L}$ on both ADP and TADP was investigated at temperatures of $25,35,45$, and $55^{\circ} \mathrm{C}$. The results are shown in Figure 7 . The vertical slopes of the plots for both adsorbents indicate the speedy enhancement in solid phase concentrations of $\mathrm{Cu}(\mathrm{II})$ with the increase of liquid phase concentrations from 10 to $50 \mathrm{mg} / \mathrm{L}$. Although, when compared to untreated adsorbents (max $290 \mathrm{mg} / \mathrm{g}$ ), the $\mathrm{H}_{2} \mathrm{O}_{2}$ treated adsorbents showed better adsorption capabilities (max $360 \mathrm{mg} / \mathrm{g}$ ). For the graph of initial 
concentration $\left(\mathrm{C}_{\mathrm{e}}\right)$ vs. adsorption capacities $\left(\mathrm{q}_{\mathrm{e}}\right)$ of $\mathrm{Cu}(\mathrm{II})$ ions at different temperatures, the correlation coefficient $\left(\mathrm{R}^{2}\right)$ ranged from 0.9816 to 0.9926 . Higher adsorbate concentration gradients may act as a driving factor for mass transfer between the solution and solid phases to overcome the resistance barrier [39].
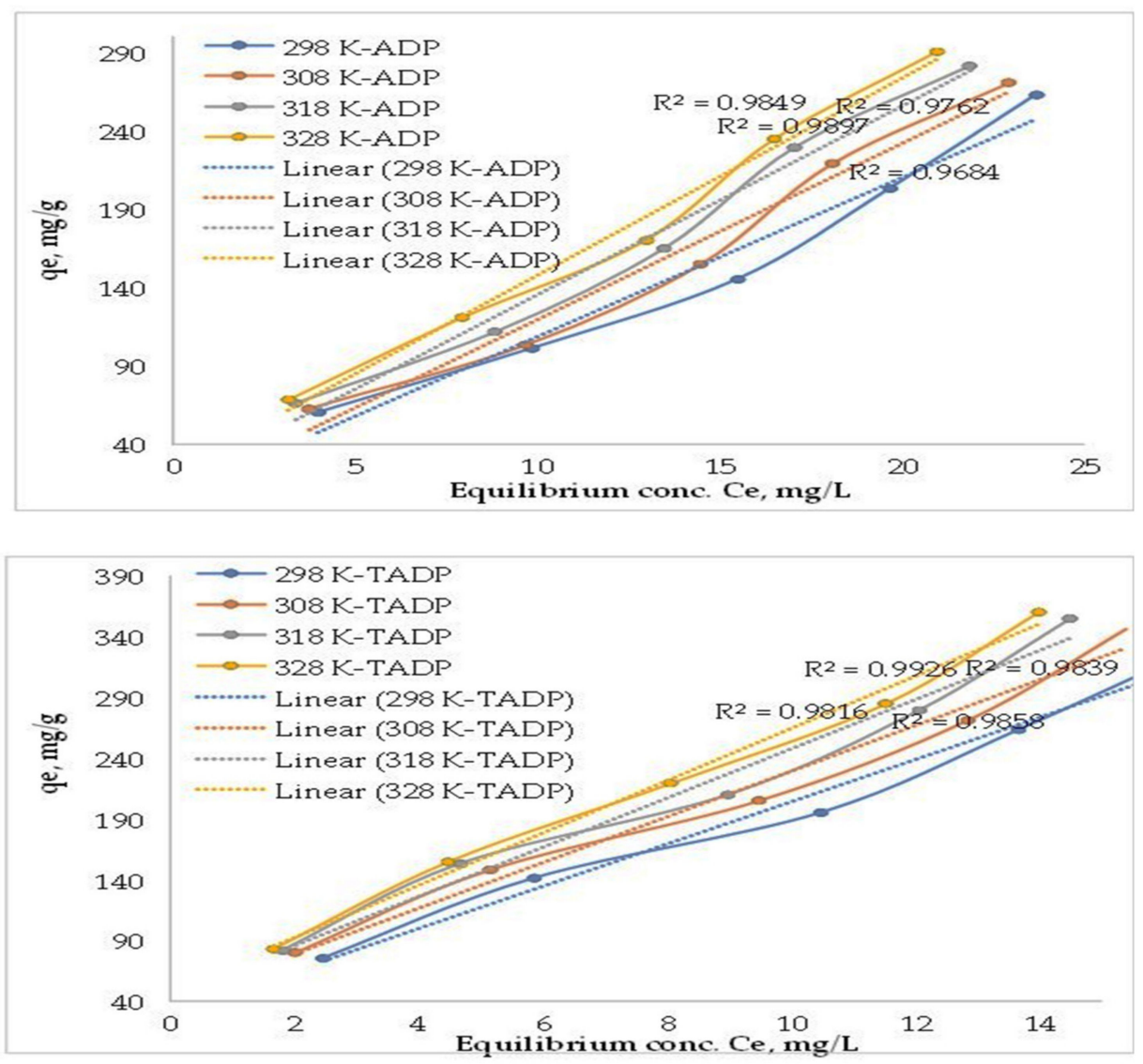

Figure 7. Effect of initial metal concentration and temperature (experimental conditions: initial conc: $25 \mathrm{mg} / \mathrm{L}$; adsorbent weight: $0.005 \mathrm{~g}$; volume: $0.05 \mathrm{~L}$; temperature: $25^{\circ} \mathrm{C}$; contact time: $5 \mathrm{~h}$; shaker speed: $100 \mathrm{rpm})$.

The slopes of the plots eventually fell and became nearly parallel to the x-axis, suggesting that the adsorbent surfaces were saturated with $\mathrm{Cu}$ (II) ions. The rise in $\mathrm{Cu}$ (II) ions adsorption capacity on both ADP and TADP with temperature supports the endothermic adsorption process, and the results are consistent with the literature on metal ion adsorption [44].

$\mathrm{Cu}(\mathrm{II})$ ions adsorption capacities on ADP were $60.0-2263.0 \mathrm{mg} / \mathrm{g}$ at $298 \mathrm{~K}$, while TADP adsorption capacities (qe) were found to be in the range of $75.3-333.0 \mathrm{mg} / \mathrm{g}$ for concentrations ranging from 10 to $50 \mathrm{mg} / \mathrm{L}$. The qe values were increased with increasing temperature and were found to be highest at $318 \mathrm{~K}$ for all analyzed concentrations, and the solid phase concentration ( $\mathrm{q}_{\mathrm{e}}$ ) of $\mathrm{Cu}(\mathrm{II})$ ions on ADP were $68.2-290.0 \mathrm{mg} / \mathrm{g}$, while the ranges at temperature $298 \mathrm{~K}$ were $60.0-2263.0 \mathrm{mg} / \mathrm{g}$. Similarly, the solid phase concentration on TADP was found to be in the range of $83.2-360.0 \mathrm{mg} / \mathrm{g}$, while the qe were in the ranges of $75.3-333.0 \mathrm{mg} / \mathrm{g}$ at temperature 318 , and $298 \mathrm{~K}$, respectively. It is obvious that a better adsorption of the target metals was achieved for the treated adsorbent material.

\subsubsection{Effects of Contact Time}

$\mathrm{Cu}(\mathrm{II})$ ions adsorption on ADP and TADP as a function of contact duration was investigated for $\mathrm{Cu}$ (II) concentrations ranging from 5 to $1440 \mathrm{~min}$. Figure 8 shows how contact time (up to $360 \mathrm{~min}$ ) affects $\mathrm{Cu}$ (II) adsorption. 

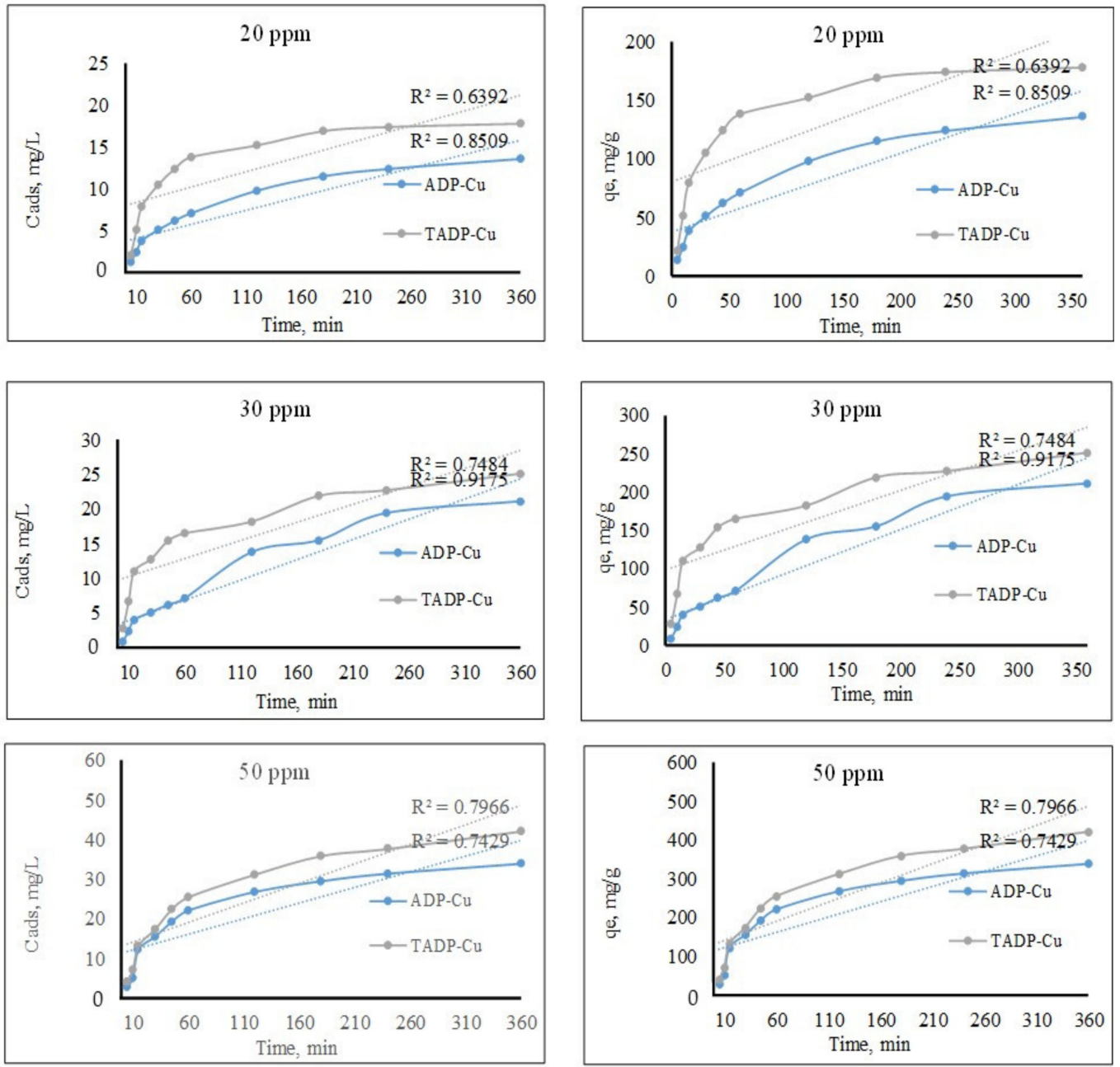

Figure 8. Effect of contact time at concentrations 20,30, and $50 \mathrm{mg} / \mathrm{L}$ of the adsorbates (experimental conditions: Co: $25 \mathrm{mg} / \mathrm{L}$; m: $0.005 \mathrm{~g}$; V: $0.05 \mathrm{~L}$; T: $25^{\circ} \mathrm{C}$; agitation speed: $100 \mathrm{rpm}$ ).

The higher contact time was neglected due to a very minor increase in the adsorption capacities after $360 \mathrm{~min}$. $\mathrm{Cu}$ (II) adsorption was detected on ADP and TADP at a slow rate, reaching equilibrium adsorption in $360 \mathrm{~min}(6 \mathrm{~h})$. For $\mathrm{Cu}(\mathrm{II})$ ions adsorption, the correlation coefficient $\left(R^{2}\right)$ for the graph of time (min) vs. adsorbed concentration (Cads) and Time vs. Qe (mg/g) at concentration levels 20,30 , and $50 \mathrm{mg} / \mathrm{L}$ was found to be in the range of 0.6392 to 0.9175 . The equilibrium adsorption capacity (Qe) of $\mathrm{Cu}$ (II) ions on ADP was 136,211 , and $339 \mathrm{mg} / \mathrm{g}$, for concentrations of 20,30 , and $50 \mathrm{ppm}$, respectively, and 178, 251, and $421 \mathrm{mg} / \mathrm{g}$ for concentrations of 20,30, and $50 \mathrm{ppm}$, respectively. The results show that ADP as produced materials have lower adsorption capabilities than TADP.

\subsubsection{Adsorption Modeling}

Equilibrium Isotherm

During the isotherm study, linear isothermal models such as the Langmuir and Freundlich [45] isotherms were applied.

The non-linearized and linearized Langmuir isotherm models are written as follows:

$$
\begin{gathered}
\mathrm{q}_{\mathrm{e}}=\frac{q_{m} K_{L} \mathrm{C}_{\mathrm{e}}}{1+K_{L} \mathrm{C}_{\mathrm{e}}} \\
\frac{\mathrm{C}_{\mathrm{e}}}{\mathrm{q}_{\mathrm{e}}}=\frac{1}{K_{L} q_{m}}+\frac{1}{q_{m}} \times \mathrm{C}_{\mathrm{e}},
\end{gathered}
$$


where $q_{m}(\mathrm{mg} / \mathrm{g})$ symbolizes maximum monolayer adsorption capacity and $K_{L}(\mathrm{~L} / \mathrm{mg})$ denotes the process heat of adsorption.

The Freundlich isotherm, on the other hand, is stated as in [45] in both linear and non-linear models:

$$
\begin{gathered}
\mathrm{q}_{\mathrm{e}}=K_{F} \times \mathrm{C}_{\mathrm{e}}^{1 / n}, \\
\log \mathrm{q}_{\mathrm{e}}=\log K_{F}+\frac{1}{n} \log \mathrm{C}_{\mathrm{e}} .
\end{gathered}
$$

The Freundlich constants for bonding energy and deviation from linearity in adsorption are $K_{F}\left((\mathrm{mg} / \mathrm{g})(\mathrm{L} / \mathrm{mg})^{(1 / \mathrm{n})}\right)$ and $n$, respectively. When the value of $n$ in the equation is equal to $1,<1$ or $>1$, the adsorption process is said to be linear, chemical, or physical, respectively.

The adsorption of $\mathrm{Cu}(\mathrm{II})$ on ADP and TADP adsorbents was carried out at varied temperatures and the corresponding parameters for adsorption are given in Table 2. The regression coefficient $\left(\mathrm{R}^{2}\right)$ of Langmuir isotherm model for $\mathrm{Cu}(\mathrm{II})$ ions adsorption on both ADP and TADP materials at various temperatures was found to be closer to unity than the Freundlich model, which is consistent with previously reported results of metal ion removal [39]. Furthermore, the appropriateness of the Langmuir model shows that monolayer metal ions cover both ADP and TADP adsorbents at various temperatures. The maximum adsorption capacity $\left(q_{m}\right)$ for $\mathrm{Cu}(\mathrm{II})$ was found to be increased from $666.67 \mathrm{mg} / \mathrm{g}$ $(666.67 / 63.546=10.491 \mathrm{mmol} / \mathrm{g})$ to $1428.57 \mathrm{mg} / \mathrm{g}(1428.57 / 63.546=22.481 \mathrm{mmol} / \mathrm{g})$ for TADP for changing the temperature from $298 \mathrm{~K}$ to $328 \mathrm{~K}$. On the other hand, for the same temperature changes the $q_{m}$ of ADP was changed from $348.0 \mathrm{mg} / \mathrm{g}$ $(348.0 / 63.546=5.476 \mathrm{mmol} / \mathrm{g})$ to $1111.1 \mathrm{mg} / \mathrm{g}(1111.1 / 63.546=17.485 \mathrm{mmol} / \mathrm{g})$. The adsorbents and $\mathrm{Cu}$ (II) ions may have collided more frequently as the temperature increased, enhancing the adsorption capability of the materials. As the temperature rises, the surface bindings of the adsorbents are ruptured, exposing the active site to a greater extent and therefore increasing the adsorption of the metal ions.

\begin{tabular}{|c|c|c|c|c|}
\hline \multirow{2}{*}{ Isotherm } & \multicolumn{4}{|c|}{ Temperature, $\mathrm{K}$} \\
\hline & 298 & 308 & 318 & 328 \\
\hline \multicolumn{5}{|c|}{ TADP } \\
\hline \multicolumn{5}{|l|}{ Langmuir } \\
\hline$K_{L}(\mathrm{~L} / \mathrm{mg})$ & 0.057915 & 0.01449 & 0.01289 & 0.01107 \\
\hline $\mathrm{R}^{2}$ & 0.9889 & 0.9972 & 0.9986 & 0.9932 \\
\hline \multicolumn{5}{|l|}{ Freundlich } \\
\hline$K F(\mathrm{mg} / \mathrm{g})(\mathrm{L} / \mathrm{mg})^{1 / \mathrm{n}}$ & 19.1134 & 37.6320 & 53.6320 & 57.0176 \\
\hline$n$ & 1.2449 & 1.2358 & 1.2858 & 1.4550 \\
\hline $\mathrm{R}^{2}$ & 0.9096 & 0.9253 & 0.9170 & 0.9250 \\
\hline \multicolumn{5}{|c|}{ ADP } \\
\hline \multicolumn{5}{|l|}{ Langmuir } \\
\hline$K_{L}(\mathrm{~L} / \mathrm{mg})$ & $\begin{array}{c}340.0 \\
0.03275\end{array}$ & 0.07048 & 0.01289 & 0.03904 \\
\hline$R^{2}$ & 0.9853 & 0.9901 & 0.9932 & 0.9891 \\
\hline \multicolumn{5}{|l|}{ Freundlich } \\
\hline$K F(\mathrm{mg} / \mathrm{g})(\mathrm{L} / \mathrm{mg})^{1 / \mathrm{n}}$ & 18.52 & 23.43 & 23.69 & 48.56 \\
\hline $\mathrm{n}$ & 1.0132 & 1.2168 & 1.6211 & 1.7621 \\
\hline $\mathrm{R}^{2}$ & 0.7192 & 0.8586 & 0.8914 & 0.8979 \\
\hline
\end{tabular}

Table 2. Isotherm parameters for the adsorption of $\mathrm{Cu}(\mathrm{II})$ on ADP and TADP.

The separation factor $\left(K_{L}\right)$ for $\mathrm{Cu}(\mathrm{II})$ ions adsorption on ADP and TADP was in the range of 0.01 to 0.08 at the investigated temperature ranges (298 to $328 \mathrm{~K}$ ), indicating an adsorption process. The $K_{F}$ values enhanced as the temperature increased due to the 
increased contact between metal ions adsorbents, and $\mathrm{n}>1$ for both adsorbents confirm the physical adsorption process (Table 2).

\subsection{Adsorption Kinetics}

Using the adsorption kinetic data and the models, the Pseudo-first [45] and Pseudosecond-order [45] kinetics models in their linear form were investigated to determine the kinetic parameters. The linearized kinetic models are expressed as follows:

$$
\begin{gathered}
\log \left(q_{e 1}-q_{t}\right)=\log q_{e 1}-\frac{k_{1}}{2.303} \times t, \\
\frac{t}{q_{t}}=\frac{1}{k_{2} q_{e 2}{ }^{2}}+\frac{1}{q_{e 2}} \times \mathrm{t},
\end{gathered}
$$

where $q_{e 1}, q_{e 2}$, and $q_{t}$ signify the pseudo-first order model, the pseudo-second order model at equilibriums, and the pseudo-third order model at time $t$, respectively. Furthermore, $k_{1}$ and $k_{2}$ are the rate constants for pseudo-first-order and pseudo-second-order kinetics, respectively.

The obtained kinetic parameters for $\mathrm{Cu}(\mathrm{II})$ adsorption data on both ADP and TADP adsorbents are depicted in Table 3. Based on higher $\mathrm{R} 2$ values, the $\mathrm{Cu}$ (II) ions adsorption data in all tested adsorbents supports a kinetic model with a pseudo-second order (closer to unity). The close agreement between experimental and calculated adsorption capabilities $\left(\mathrm{q}_{\mathrm{e}, \mathrm{exp}}\right)$ further confirmed the findings, showing that $\mathrm{Cu}(\mathrm{II})$ ion adsorption on ADP and TADP was a chemical adsorption process rather than a conventional mass transport phenomenon [46]. Similar findings were described by Trikkaliotis et al. for $\mathrm{Cu}(\mathrm{II}))$ adsorption onto chitin based materials [47].

Table 3. Kinetic parameters calculated for the adsorption of $\mathrm{Cu}(\mathrm{II})$ on ADP and TADP adsorbents (initial concentration, $\mathrm{C}_{0}$ for $\mathrm{Cu}(\mathrm{II})$ was $20 \mathrm{mg} / \mathrm{L}$ ).

\begin{tabular}{ccc}
\hline Kinetics Model & ADP & TADP \\
\cline { 2 - 3 } & \multicolumn{2}{c}{ Cu(II) 20 mg/L } \\
\hline $\mathrm{q}_{\mathrm{e}, \text { exp }}(\mathrm{mg} / \mathrm{g})$ & 136 & 178 \\
\hline Pseudo-first-order & & \\
$\mathrm{q}_{\mathrm{e} 1, \text { cal }}(\mathrm{mg} / \mathrm{g})$ & 118.38 & 126.88 \\
$\mathrm{~K}_{1}(1 / \mathrm{min})$ & 0.0097 & 0.0145 \\
$\mathrm{R}^{2}$ & 0.991 & 0.978 \\
Pseudo-second-order & 145.25 & 189.07 \\
$\mathrm{q}_{\mathrm{e} 2, \text { cal }}(\mathrm{mg} / \mathrm{g})$ & 0.00005 & 0.00003 \\
$\mathrm{k}_{2}(\mathrm{~g} / \mathrm{mg}$-min) & 0.996 & 0.995 \\
$\mathrm{R}^{2}$ & &
\end{tabular}

\subsection{Adsorption Thermodynamics}

Van't Hoff plots [48] are used to estimate the thermodynamic parameters related to $\mathrm{Cu}(\mathrm{II})$ ions adsorption on ADP and TADP, such as standard free entropy changes $\left(\Delta \mathrm{S}^{\circ}\right)$, enthalpy changes $\left(\Delta \mathrm{H}^{\circ}\right)$, and free energy changes $\left(\Delta \mathrm{G}^{\circ}\right)$, and the results are shown in Table 4. $\mathrm{Cu}$ (II) ions adsorption on both ADP and TADP was endothermic, as demonstrated by positive $\Delta \mathrm{H}^{\circ}$ values at all concentrations tested. The $\Delta \mathrm{S}^{\circ}$ values for both adsorbents were all positive, suggesting a random adsorption process due to energy redistribution between $\mathrm{Cu}(\mathrm{II})$ ions and the adsorbent [49]. Moreover, the $\Delta \mathrm{G}^{\circ}$ values for $\mathrm{Cu}$ (II) adsorption were negative for all types of adsorbents, suggesting the adsorption process to be spontaneous. The negative $\Delta \mathrm{G}^{\circ}$ values rose with an increase in temperature, indicating that the adsorption process favored spontaneity [41]. 
Table 4. Thermodynamic parameters for the adsorption of $\mathrm{Cu}(\mathrm{II})$ on ADP and TADP adsorbents (initial concentration, $\mathrm{C}_{0}$ was $20 \mathrm{mg} / \mathrm{L}$ ).

\begin{tabular}{|c|c|c|c|c|c|c|c|}
\hline \multirow{2}{*}{ Adsorbents } & \multirow{2}{*}{$\begin{array}{c}\text { Concentration } \\
\mathrm{mg} / \mathrm{L}\end{array}$} & \multirow{2}{*}{$\frac{\Delta \mathrm{H}^{\circ}}{(\mathrm{kJ} / \mathrm{mol})}$} & \multirow{2}{*}{$\frac{\Delta S^{\circ}}{(\mathrm{J} / \mathrm{mol}-\mathrm{K})}$} & \multicolumn{4}{|c|}{$\Delta \mathrm{G}^{\circ}(\mathrm{kJ} / \mathrm{mol})$} \\
\hline & & & & $298 \mathrm{~K}$ & $308 \mathrm{~K}$ & $318 \mathrm{~K}$ & $328 \mathrm{~K}$ \\
\hline \multirow{4}{*}{$\mathrm{ADP}$} & 20 & 2608.34 & 86.29 & -156.34 & -566.44 & -951.43 & -1020.48 \\
\hline & 30 & 2122.10 & 69.92 & -165.79 & -341.35 & -708.64 & -916.92 \\
\hline & 40 & 1810.70 & 60.54 & -419.21 & -479.90 & -562.61 & -821.86 \\
\hline & 50 & 1762.03 & 59.16 & -64.62 & -92.97 & -423.11 & -634.68 \\
\hline \multirow{4}{*}{ TADP } & 20 & 1017.01 & 41.52 & -2167.69 & -2537.27 & -2934.88 & -3064.55 \\
\hline & 30 & 704.95 & 28.99 & -1533.09 & -1904.93 & -2098.57 & -2178.40 \\
\hline & 40 & 854.00 & 34.71 & -1786.02 & -2073.66 & -2380.42 & -2550.16 \\
\hline & 50 & 896.01 & 30.83 & -257.90 & -409.23 & -899.72 & -1004.94 \\
\hline
\end{tabular}

\subsection{Elution and Regeneration Studies}

The elution efficiency of sufficiently $\mathrm{Cu}(\mathrm{II})$ ions saturated ADP and TADP adsorbents with various eluents was tested (Figure 9). Metal ion elution from both saturated adsorbents was discovered to be modest (3.0-3.2\%) when eluted with $0.1 \mathrm{~mol} / \mathrm{L} \mathrm{NaOH}$, however $0.1 \mathrm{M}$ $\mathrm{HCl}$ caused a substantial increase in metal ion desorption for both adsorbents (84-98\%).

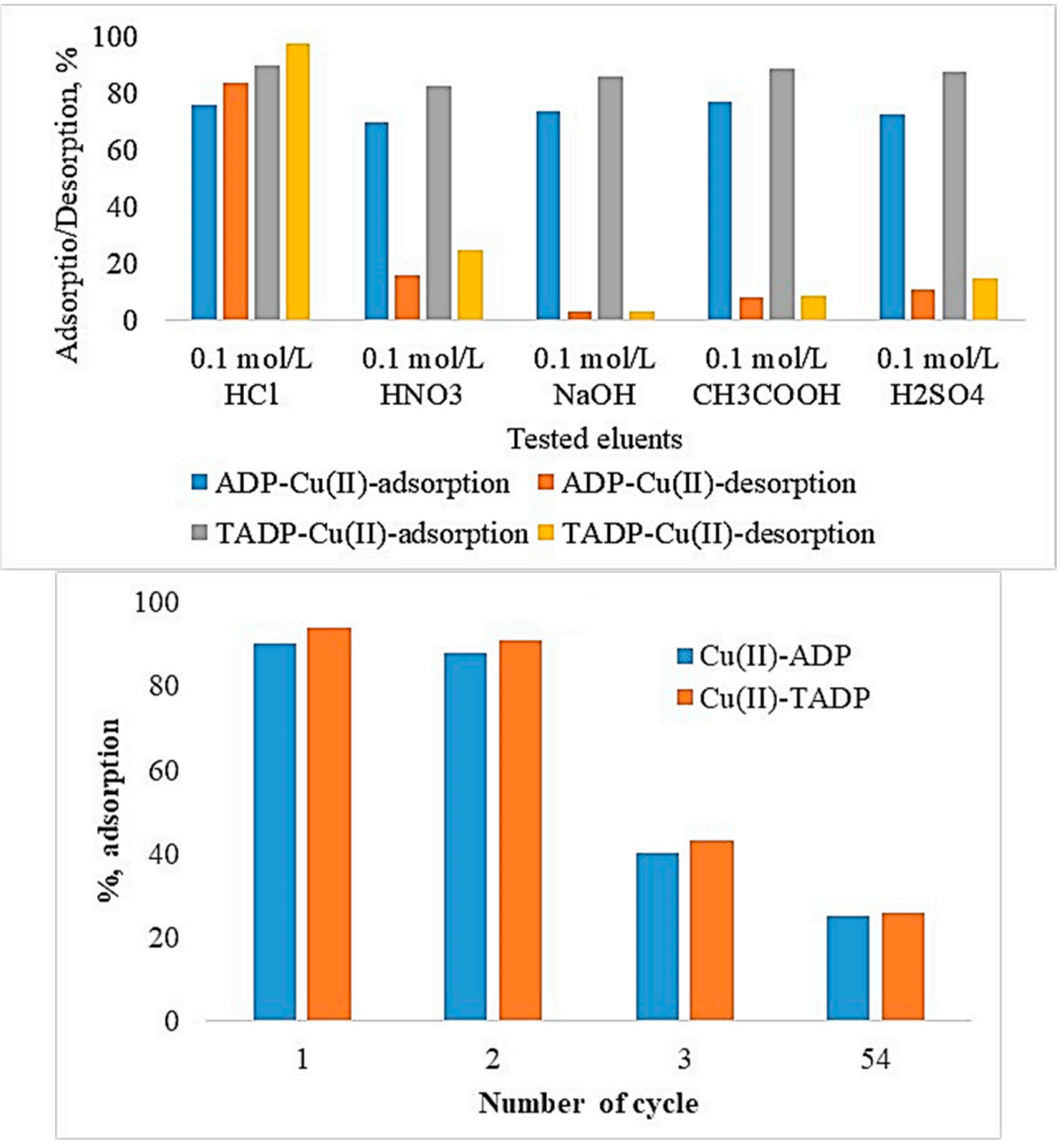

Figure 9. $\mathrm{Cu}(\mathrm{II})$ ion elution from saturated adsorbents (experimental conditions: $\mathrm{Co}: 25 \mathrm{mg} / \mathrm{L}$; m: $0.05 \mathrm{~g}$; V: $0.05 \mathrm{~L}$; $\mathrm{T}: 25^{\circ} \mathrm{C}$; contact time: $5 \mathrm{~h}$; agitation speed: $100 \mathrm{rpm}$ ). 
The order of elution efficacy with the treated eluents was as follows: $0.1 \mathrm{~mol} / \mathrm{L} \mathrm{NaOH}$ $<0.1 \mathrm{~mol} / \mathrm{L} \mathrm{CH}_{3} \mathrm{COOH}<0.1 \mathrm{~mol} / \mathrm{L} \mathrm{H}_{2} \mathrm{SO}_{4}<0.1 \mathrm{~mol} / \mathrm{L} \mathrm{HNO}_{3}<0.1 \mathrm{~mol} / \mathrm{L} \mathrm{HCl}$. The data shows that the highest $\mathrm{Cu}(\mathrm{II})$ ion elution with $\mathrm{HCl}(0.1 \mathrm{~mol} / \mathrm{L})$ was $98 \%$ for TADP and $84 \%$ for ADP. The increased desorption efficacy of $\mathrm{Cu}(\mathrm{II})$ ions with relatively strong acid can be attributed to ion-exchange adsorption, which is mediated by metal ions binding on adsorbent surfaces.

After optimizing the eluent $(\mathrm{HCl}-0.1 \mathrm{~mol} / \mathrm{L})$, the regeneration studies for the adsorbents were also carried out to estimate their reusing efficiency. A drastic decrease in $\mathrm{Cu}(\mathrm{II})$ (80-89\%) adsorption on both ADP and TADP were noticed after the second regeneration investigation. Repeated adsorption-regeneration studies may cause surface morphological deformation, which could be one of the reasons for a decrease in metal ion adsorption with increased regeneration experiments. As a result, ADP and TADP may be repurposed for $\mathrm{Cu}(\mathrm{II})$ adsorption with minimal adsorption efficiency loss during the second regeneration.

\section{Conclusions}

The optimized ADP and TADP revealed the excellent adsorption potential of $\mathrm{Cu}$ (II) in its respective adsorption methods. The biosorbent TADP showed higher adsorption capabilities compared to ADP. The $\mathrm{R}^{2}$ values for $\mathrm{C}_{\mathrm{e}}$ v.s $\mathrm{q}_{\mathrm{e}}$ graph at various temperatures for $\mathrm{Cu}(\mathrm{II})$ adsorption were found to be 0.9816 to 0.9926 , where the $\mathrm{R}^{2}$ for time (min) vs. Qe (mg/g) graph at variable concentrations ranged from 0.6392 to 0.9175 . The metal ions adsorptions by ADP and TADP were endothermic, indicating that a pseudo-secondorder kinetics model would be more appropriate in all circumstances. The Langmuir isotherm model produced somewhat better findings in comparison to the Freundlich model for both ADP and TADP, indicating monolayer coverage. Desorption experiments with $0.1 \mathrm{~mol} / \mathrm{L} \mathrm{HCl}$ yielded the highest $\mathrm{Cu}$ (II) ions recovery. The findings of the adsorption and desorption outcomes reveal that the synthesized materials have the potential to be useful for removing heavy metal ions and for other contaminants as well from a variety of media while maintaining a safe environment.

Author Contributions: Conceptualization, M.A. and S.I.A.-R.; methodology, S.M.W. and M.R.K.; validation, M.A. and S.M.W.; formal analysis, S.M.W.; investigation, M.R.K. and M.S.I.; data curation, M.A.; writing—original draft preparation, S.M.W. and M.R.K. writing—review and editing, M.A. and S.I.A.-R.; supervision, M.A.; project administration, M.A.; funding acquisition, M.A. All authors have read and agreed to the published version of the manuscript.

Funding: This Project was funded by the National Plan for Science, Technology, and Innovation (MAARIFAH), King Abdulaziz City for Science and Technology (KACST), Kingdom of Saudi Arabia, Award Number (14-ENV2458-02).

Institutional Review Board Statement: Not applicable.

Informed Consent Statement: Not applicable.

Acknowledgments: This Project was funded by the National Plan for Science, Technology, and Innovation (MAARIFAH), King Abdulaziz City for Science and Technology (KACST), Kingdom of Saudi Arabia, Award Number (14-ENV2458-02).

Conflicts of Interest: The authors declare no conflict of interest.

\section{References}

1. Xu, D.-M.; Fu, R.-B.; Tong, Y.-H.; Shen, D.-L.; Guo, X.-P. The potential environmental risk implications of heavy metals based on their geochemical and mineralogical characteristics in the size-segregated zinc smelting slags. J. Clean. Prod. 2021, 315, 128199. [CrossRef]

2. Zhang, Y.; Wu, C.; Liu, H.; Khan, M.R.; Zhao, Z.; He, G.; Luo, A.; Zhang, J.; Deng, R.; He, Q. Label-free DNAzyme assays for dually amplified and one-pot detection of lead pollution. J. Hazard. Mater. 2021, 406, 124790. [CrossRef]

3. Khan, M.R.; Ahmad, N.; Ouladsmane, M.; Azam, M. Heavy Metals in Acrylic Color Paints Intended for the School Children Use: A Potential Threat to the Children of Early Age. Molecules 2021, 26, 2375. [CrossRef]

4. Mahurpawar, M. Effects of heavy metals on human health. Int. J. Res. Granthaalayah 2015, 3, 1-7. [CrossRef] 
5. SenthilKumar, P.; Ramalingam, S.; Sathyaselvabala, V.; Kirupha, S.D.; Sivanesan, S. Removal of copper (II) ions from aqueous solution by adsorption using cashew nut shell. Desalination 2011, 266, 63-71. [CrossRef]

6. Zhu, C.S.; Wang, L.P.; Chen, W.B. Removal of Cu (II) from aqueous solution by agricultural by-product: Peanut hull. J. Hazard. Mater. 2009, 168, 739-746. [CrossRef] [PubMed]

7. Wu, W.; Yang, Y.; Zhou, H.; Ye, T.; Huang, Z.; Liu, R.; Kuang, Y. Highly efficient removal of Cu (II) from aqueous solution by using graphene oxide. Water Air Soil Pollut. 2013, 224, 1-8. [CrossRef]

8. Singha, B.; Das, S.K. Adsorptive removal of $\mathrm{Cu}$ (II) from aqueous solution and industrial effluent using natural/agricultural wastes. Colloids Surf. B Biointerfaces 2013, 107, 97-106. [CrossRef]

9. Edding, M.; Tala, F. Copper transfer and influence on a marine food chain. Bull. Environ. Contam. Toxicol. 1996, 57, 617-624. [CrossRef]

10. Stenhammar, L. Diarrhoea following contamination of drinking water with copper. Eur. J. Med. Res. 1999, 4, $217-218$.

11. Ross, A. Vomiting and Diarrhoea due to Copper in Stewed Apples. Lancet 1955, 87-88. [CrossRef]

12. Bergeron, C.; Petrunka, C.; Weyer, L. Copper/zinc superoxide dismutase expression in the human central nervous system. Correlation with selective neuronal vulnerability. Am. J. Pathol. 1996, 148, 273. [PubMed]

13. Araya, M.; Peña, C.; Pizarro, F.; Olivares, M. Gastric response to acute copper exposure. Sci. Total Environ. 2003, 303, 253-257. [CrossRef]

14. Acrylamide, O. National Primary Drinking Water Regulations. Kidney 2009, 2, 1-7.

15. Li, Y.; Trush, M.A.; Yager, J.D. DNA damage caused by reactive oxygen species originating from a copper-dependent oxidation of the 2-hydroxy catechol of estradiol. Carcinogenesis 1994, 15, 1421-1427. [CrossRef]

16. Starkebaum, G.; Harlan, J.M. Endothelial cell injury due to copper-catalyzed hydrogen peroxide generation from homocysteine. J. Clin. Investig. 1986, 77, 1370-1376. [CrossRef] [PubMed]

17. Renfew, M.M. NIOSH Pocket Guide to Chemical Hazards; ACS Publications; US Department of Health and Human ServicesNational Institute for Occupational Safety and Health: Washington, DC, USA, 1991.

18. Bashir, A.; Malik, L.A.; Ahad, S.; Manzoor, T.; Bhat, M.A.; Dar, G.; Pandith, A.H. Removal of heavy metal ions from aqueous system by ion-exchange and biosorption methods. Environ. Chem. Lett. 2019, 17, 729-754. [CrossRef]

19. Zhang, Q.; Hou, Q.; Huang, G.; Fan, Q. Removal of heavy metals in aquatic environment by graphene oxide composites: A review. Environ. Sci. Pollut. Res. 2020, 27, 190-209. [CrossRef] [PubMed]

20. Un, U.T.; Ocal, S.E. Removal of heavy metals (Cd, Cu, Ni) by electrocoagulation. Int. J. Environ. Sci. Dev. 2015, 6, 425. [CrossRef]

21. Li, Y.; Yang, L.; Xu, Z.; Sun, Q. Separation and Recovery of Heavy Metals from Waste Water Using Synergistic Solvent Extraction; IOP Conference Series: Materials Science and Engineering; IOP Publishing: Bristol, UK, 2017.

22. BrbootI, M.M.; AbiD, B.A.; Al-ShuwaikI, N.M. Removal of heavy metals using chemicals precipitation. Eng. Technol. J 2011, 29, 595-612.

23. Huang, Y.; Wu, D.; Wang, X.; Huang, W.; Lawless, D.; Feng, X. Removal of heavy metals from water using polyvinylamine by polymer-enhanced ultrafiltration and flocculation. Sep. Purif. Technol. 2016, 158, 124-136. [CrossRef]

24. Lakherwal, D. Adsorption of heavy metals: A review. Int. J. Environ. Res. Dev. 2014, 4, 41-48.

25. Shahrokhi-Shahraki, R.; Benally, C.; El-Din, M.G.; Park, J. High efficiency removal of heavy metals using tire-derived activated carbon vs commercial activated carbon: Insights into the adsorption mechanisms. Chemosphere 2021, 264, 128455. [CrossRef]

26. Sunil, K.; Karunakaran, G.; Yadav, S.; Padaki, M.; Zadorozhnyy, V.; Pai, R.K. Al-Ti2O6 a mixed metal oxide based composite membrane: A unique membrane for removal of heavy metals. Chem. Eng. J. 2018, 348, 678-684. [CrossRef]

27. Wu, S.; Xu, Y.; Sun, J.; Cao, Z.; Zhou, J.; Pan, Y.; Qian, G. Inhibiting evaporation of heavy metal by controlling its chemical speciation in MSWI fly ash. Fuel 2015, 158, 764-769. [CrossRef]

28. Karnib, M.; Kabbani, A.; Holail, H.; Olama, Z. Heavy metals removal using activated carbon, silica and silica activated carbon composite. Energy Procedia 2014, 50, 113-120. [CrossRef]

29. Yu, B.; Zhang, Y.; Shukla, A.; Shukla, S.S.; Dorris, K.L. The removal of heavy metal from aqueous solutions by sawdust adsorption-removal of copper. J. Hazard. Mater. 2000, 80, 33-42. [CrossRef]

30. Lu, S.; Gibb, S.W. Copper removal from wastewater using spent-grain as biosorbent. Bioresour. Technol. 2008, 99, 1509-1517. [CrossRef] [PubMed]

31. Wu, Y.; Zhang, L.; Gao, C.; Ma, J.; Ma, X.; Han, R. Adsorption of copper ions and methylene blue in a single and binary system on wheat straw. J. Chem. Eng. Data 2009, 54, 3229-3234. [CrossRef]

32. Ofomaja, A.; Naidoo, E.; Modise, S. Removal of copper (II) from aqueous solution by pine and base modified pine cone powder as biosorbent. J. Hazard. Mater. 2009, 168, 909-917. [CrossRef] [PubMed]

33. Larous, S.; Meniai, A. Removal of copper (II) from aqueous solution by agricultural by-products-sawdust. Energy Procedia 2012, 18, 915-923.

34. Gündoğan, R.; Acemioğlu, B.; Alma, M.H. Copper (II) adsorption from aqueous solution by herbaceous peat. J. Colloid Interface Sci. 2004, 269, 303-309. [CrossRef]

35. Aksu, Z.; İşoğlu, İ.A. Removal of copper (II) ions from aqueous solution by biosorption onto agricultural waste sugar beet pulp. Process Biochem. 2005, 40, 3031-3044. [CrossRef] 
36. Jawad, A.H.; Abdulhameed, A.S.; Hanafiah, M.; ALOthman, Z.A.; Khan, M.R.; Surip, S. Numerical desirability function for adsorption of methylene blue dye by sulfonated pomegranate peel biochar: Modeling, kinetic, isotherm, thermodynamic, and mechanism study. Korean J. Chem. Eng. 2021, 38, 1-11. [CrossRef]

37. Jawad, A.H.; Bardhan, M.; Islam, M.A.; Islam, M.A.; Syed-Hassan, S.S.A.; Surip, S.; ALOthman, Z.A.; Khan, M.R. Insights into the modeling, characterization and adsorption performance of mesoporous activated carbon from corn cob residue via microwave-assisted H3PO4 activation. Surf. Interfaces 2020, 21, 100688. [CrossRef]

38. Jawad, A.H.; Abdulhameed, A.S.; Wilson, L.D.; Syed-Hassan, S.S.A.; ALOthman, Z.A.; Khan, M.R. High surface area and mesoporous activated carbon from $\mathrm{KOH}$-activated Dragon fruit peels for methylene blue dye adsorption: Optimization and mechanism study. Chin. J. Chem. Eng. 2021, 32, 281-290. [CrossRef]

39. Azam, M.; Wabaidur, S.M.; Khan, M.R.; Al-Resayes, S.I.; Islam, M.S. Removal of Chromium (III) and Cadmium (II) Heavy Metal Ions from Aqueous Solutions Using Treated Date Seeds: An Eco-Friendly Method. Molecules 2021, 26, 3718. [CrossRef]

40. Idowu, A.T.; Igiehon, O.O.; Adekoya, A.E.; Idowu, S. Dates palm fruits: A review of their nutritional components, bioactivities and functional food applications. AIMS Agric. Food 2020, 5, 734-755. [CrossRef]

41. Khan, M.A.; Otero, M.; Kazi, M.; Alqadami, A.A.; Wabaidur, S.M.; Siddiqui, M.R.; Alothman, Z.A.; Sumbul, S. Unary and binary adsorption studies of lead and malachite green onto a nanomagnetic copper ferrite/drumstick pod biomass composite. J. Hazard. Mater. 2019, 365, 759-770. [CrossRef]

42. Tran, H.N.; You, S.-J.; Chao, H.-P. Thermodynamic parameters of cadmium adsorption onto orange peel calculated from various methods: A comparison study. J. Environ. Chem. Eng. 2016, 4, 2671-2682. [CrossRef]

43. Reddy, D.H.K.; Seshaiah, K.; Reddy, A.; Lee, S. Optimization of Cd (II), Cu (II) and Ni (II) biosorption by chemically modified Moringa oleifera leaves powder. Carbohydr. Polym. 2012, 88, 1077-1086. [CrossRef]

44. Alqadami, A.A.; Khan, M.A.; Siddiqui, M.R.; Alothman, Z.A. Development of citric anhydride anchored mesoporous MOF through post synthesis modification to sequester potentially toxic lead (II) from water. Microporous Mesoporous Mater. 2018, 261, 198-206. [CrossRef]

45. Wabaidur, S.M.; Khan, M.A.; Siddiqui, M.R.; Otero, M.; Jeon, B.-H.; Alothman, Z.A.; Hakami, A.A.H. Oxygenated functionalities enriched MWCNTs decorated with silica coated spinel ferrite-A nanocomposite for potentially rapid and efficient de-colorization of aquatic environment. J. Mol. Liq. 2020, 317, 113916. [CrossRef]

46. Khan, M.A.; Alqadami, A.A.; Otero, M.; Siddiqui, M.R.; Alothman, Z.A.; Alsohaimi, I.; Rafatullah, M.; Hamedelniel, A.E. Heteroatom-doped magnetic hydrochar to remove post-transition and transition metals from water: Synthesis, characterization, and adsorption studies. Chemosphere 2019, 218, 1089-1099. [CrossRef]

47. Trikkaliotis, D.G.; Christoforidis, A.K.; Mitropoulos, A.C.; Kyzas, G.Z. Adsorption of copper ions onto chitosan/poly (vinyl alcohol) beads functionalized with poly (ethylene glycol). Carbohydr. Polym. 2020, 234, 115890. [CrossRef] [PubMed]

48. Lima, É.C.; Adebayo, M.A.; Machado, F.M. Kinetic and equilibrium models of adsorption. In Carbon Nanomaterials as Adsorbents for Environmental and Biological Applications; Springer: Berlin/Heidelberg, Germany, 2015; pp. 33-69.

49. Argun, M.E.; Dursun, S.; Ozdemir, C.; Karatas, M. Heavy metal adsorption by modified oak sawdust: Thermodynamics and kinetics. J. Hazard. Mater. 2007, 141, 77-85. [CrossRef] [PubMed] 